\title{
A enunciação na semiótica visual, especialmente na pintura religiosa
}

\author{
Etienne Alfred Higuet ${ }^{*}$
}

\section{Resumo}

O presente artigo pretende mostrar como a teoria semiótica da interpretação de textos nos permite acessar à leitura de textos religiosos visuais e ao conhecimento que eles contêm e pretendem transmitir. A semiologia das imagens estuda as imagens como textos ou discursos e, no caso das imagens religiosas, como textos que remetem a outro texto, isto é, à religião como sistema de comunicação e elaboração de mensagens. Em consequência, as teorias da enunciação elaboradas em função dos textos linguísticos devem poder ser transpostas para a semiótica visual. Podemos encontrar nas imagens um correspondente analógico da enunciação linguística: a enunciação visual. Serão analisadas as modalidades pessoal, temporal e espacial da enunciação enunciada, com exemplos tirados da pintura religiosa ocidental.

Palavras-chave: semiótica visual, enunciação enunciada, reflexividade, sujeito, tempo, espaço.

\section{Enunciation in visual semiotics, especially in religious painting}

\section{Abstract}

This article aims to show how the semiotic theory of text interpretation allows us to access the reading of visual religious texts and the knowledge they contain and intend to transmit. The semiology of images studies images as texts or discourses and, in the case of religious images, as texts that refer to another text, that is, religion as a system of communication and elaboration of messages. Consequently, the theories of enunciation elaborated according to linguistic texts should be able to be transposed into visual semiotics. We can find in the images an analog correspondent of linguistic enunciation: visual enunciation. The personal, temporal

* Graduado em Filosofia e Teologia, Doutor em Ciências teológicas e religiosas pela Universidade Católica de Louvain (Bélgica), Professor aposentado da Universidade Metodista de São Paulo, etienne.higuet@gmail.com, Lattes: http://lattes.cnpq. br/5600938581821983. 
and spatial modalities of the enunciated enunciation will be analyzed, with examples taken from Western religious painting.

Keywords: visual semiotics, enunciated enunciation, reflexivity, subject, time, space.

\section{Enunciación en semiótica visual, especialmente en pintura religiosa}

\section{Resumen}

Este artículo pretende mostrar cómo la teoría semiótica de la interpretación de textos nos permite acceder a la lectura de textos religiosos visuales y el conocimiento que contienen y pretenden transmitir. La semiología de las imágenes estudia las imágenes como textos o discursos y, en el caso de las imágenes religiosas, como textos que se refieren a otro texto, es decir, la religión como sistema de comunicación y elaboración de mensajes. En consecuencia, las teorías de enunciación elaboradas según textos lingüísticos deberían poder ser transpuestas a la semiótica visual. Podemos encontrar en las imágenes un corresponsal analógico de enunciación lingüística: la enunciación visual. Se analizarán las modalidades personales, temporales y espaciales de la enunciación enunciada, con ejemplos tomados de la pintura religiosa occidental.

Palabras clave: semiótica visual, enunciación enunciada, reflexividad, sujeto, tiempo, espacio.

\section{Introdução}

Entendo a epistemologia das linguagens religiosas como teoria do conhecimento religioso alcançado por meio das diversas linguagens pelos quais a religião se expressa, sendo ela mesma uma linguagem. A maioria dos teóricos da linguagem costuma considerar o texto como a unidade básica de toda linguagem, unidade que Paul Ricoeur define como "uma unidade discursiva constituída por frases". Seguindo Rui Josgrilberg, podemos caracterizar o texto "como um entrançamento de signos e significações que armazenam sentido em significados dentro de uma unidade" (2017, p. 88). Falamos evidentemente aqui, antes de tudo, na linguagem fonética articulada, oral e escrita. Mas, para muitos teóricos, as outras linguagens, como as linguagens gestuais e as linguagens visuais, são também constituídas de textos, que necessitam, para a sua compreensão, de teorias interpretativas. Aliás, nas origens da humanidade, os textos foram "inscritos" em prioridade por imagens, bem antes da invenção de qualquer escrita. É o caso também dos textos religiosos, que são talvez os mais antigos textos visuais, na forma de imagens rupestres. Sabemos que, até hoje, as religiões continuam se expressando por meio de imagens.

O presente artigo pretende mostrar como a teoria semiótica da interpretação de textos nos permite acessar à leitura de textos religiosos 
visuais e ao conhecimento que eles contêm e pretendem transmitir. $\mathrm{O}$ artigo é, de certa forma, a continuação de um trabalho publicado como capítulo de um livro no fim do ano de 2020 (HIGUET, 2020), no qual procurei introduzir à semiótica visual, a partir da caracterização das suas principais tendências ou "escolas": a semiótica peirceana, a escola de Paris, a partir de Roland Barthes, a semiótica de Greimas e a semiótica pós-greimasiana, representada pelo Grupo $\mu$. Este breve estudo será dedicado à teoria da enunciação, uma parte da semiótica, a partir de alguns textos de Maria Giulia Dondero, da Universidade de Liège (Bélgica), que é uma das representantes mais significativas da segunda geração do grupo $\mu$. Depois de lembrar as origens da teoria da enunciação na linguística e na semiótica, mostrarei a sua importância também na interpretação da linguagem visual, terminando com uma aplicação à pintura ocidental, especialmente à pintura religiosa.

\section{A enunciação na linguística e na semiótica}

A semiologia das imagens estuda as imagens como textos ou discursos e, no caso das imagens religiosas, como textos que remetem a outro texto, isto é, à religião como sistema de comunicação e elaboração de mensagens. Roland Barthes, por exemplo, postula que os signos a serem encontrados nas imagens têm a mesma estrutura que a do signo linguístico, proposta por Saussure: um significante ligado a um significado. As imagens aparecem então como mensagens visuais, que usam diferentes categorias - ou códigos - de signos: icônicos ou analógicos, plásticos (cores, formas, composição interna, textura), linguísticos (linguagem verbal associada à imagem). Na interpretação das imagens, trata-se de encontrar os significados a partir do lugar ocupado no código pelos significantes presentes na imagem (Cf. HIGUET, 2012, p. 83-84).

Em consequência, as teorias da enunciação elaboradas em função dos textos linguísticos devem poder ser transpostas para a semiótica visual. Em particular, deve ser possível aplicar às imagens a distinção proposta por Ferdinand de Saussure, entre "fala" ou ato de falar e "língua" ou sistema permanente da linguagem. Seguindo Émile Benveniste (1966, p. 225-275), que popularizou a noção de enunciação, enquanto mediação entre a língua e a fala, a linguística da enunciação pensa que a língua contém, de modo constitutivo, indicações relativas ao ato de fala: "uma descrição geral e uma classificação das diversas situações de discursos possíveis, assim como instruções a respeito do comportamento linguístico, isto é, a especificação de certos tipos de influência que se pode exercer ao falar, e de certos papéis 
que se pode dar a si mesmo e impor aos outros (DUCROT, 2019)". Podemos dizer a mesma coisa, mutatis mutandis, a respeito da enunciação visual. Vou falar, em primeiro lugar, da enunciação linguística e tentarei mostrar, em seguida, como podemos encontrar nas imagens um correspondente analógico: a enunciação visual.

Ao usar determinadas construções linguísticas, instauramos ou contribuímos a instaurar relações específicas entre os interlocutores. É o caso de termos que remetem ao próprio ato de enunciação, como os termos que indicam o emissor (ou locutor) e o receptor (ou alocutário): pronomes pessoais "eu" e "tu", possessivos; o lugar e o momento da enunciação: advérbios "deícticos", como "aqui", "agora" e tempos verbais. Há também expressões que permitem ao locutor tomar posição em relação ao conteúdo do ato enunciativo. Portanto, uma sequência linguística oral ou escrita efetivamente realizada por um locutor ou enunciatário numa situação dada constitui um "enunciado", pois o locutor apresentou-se, ao produzir a sequência, como tendo tido o objetivo de dizer o que é dito nela. É uma ocorrência particular de entidades linguísticas abstratas ou frases, suscetíveis de serem realizadas numa infinidade de situações diferentes. Podemos dizer, então que as frases pertencem à língua e que os enunciados pertencem à fala, no sentido de Saussure (Cf. FUCHS, 2019a).

Por sua vez, a enunciação, ou o ato de fala, se distingue tanto do enunciado quando da frase: é o evento histórico que constitui, por si mesmo, a aparição de um enunciado: é o fato que uma frase foi realizada, é a própria existência do enunciado. Haverá, então, uma distinção entre o valor semântico atribuído ao enunciado, chamado de "sentido", e o valor semântico da frase, chamado de "significação". O sentido será o dado, o fato a ser explicado, especificado pela situação de discurso, ao passo que a significação será postulada como instrumento explicativo do sentido do enunciado. A frase traz instruções para a compreensão do enunciado, para a reconstrução do sentido, e não se identifica com o sentido. Assim, todo enunciado inclui, de um lado, um conteúdo representativo e, do outro lado, uma atitude tomada pelo enunciador em relação com esse conteúdo. A referência à própria enunciação pelo locutor é constitutiva do sentido do enunciado, sendo sempre, pelo menos, implícita.

Podemos encontrar uma justificativa para essa posição na distinção que Austin faz entre "atos ilocucionários" (interrogar, afirmar, mandar, prometer...) e "atos perlocucionários” (consolar, embaraçar, fazer crer...). Os 
primeiros se distinguem pela característica fundamental de que um enunciador não pode executá-los sem tentar comunicar ao destinatário que ele os executa. Ora, a realização de um ato ilocucionário contém necessariamente uma qualificação da enunciação. Por exemplo, dar uma ordem é pretender que o destinatário seja obrigado a efetuar alguma ação, e isso como consequência da enunciação que veiculou a ordem. O enunciador atribui à própria palavra o poder de criar a obrigação no destinatário. Em outros casos, a intenção aberta do enunciador de levar o seu destinatário a um certo tipo de conclusões (intenção argumentativa) é constitutiva do sentido (Cf. DUCROT, 2019).

Para Jacques Fontanille, a enunciação é tanto a "colocação em discurso" realizada pelo locutor, quanto a interação entre os sujeitos de enunciação - ela se chamará então "comunicação". É a semiótica discursiva que se ocupa com a intersecção da pragmática e da linguística da enunciação, ou da interação entre os sujeitos do discurso. Em particular, os "pontos de vista", as "perspectivas" e seus observadores, enquanto permitem a colocação em discurso do saber, regem a interação enunciativa. Para saber como o sujeito do discurso é predeterminado, até manipulado pelo próprio enunciado, para que construa uma significação e não outra, o enunciado deve ser cuidadosamente analisado pelo intérprete. Trata-se de mostrar, não apenas como o sujeito constrói a significação, mas como a assume, adotando um ponto de vista e projetando um observador. Em consequência, a subjetividade não poderá ser limitada à sua dimensão cognitiva (partilha de um saber): a dimensão prática (ou "pragmática") e a dimensão passional (ou "tímica": emergência de um afeto) da enunciação participam também da assunção da significação (FONTANILLE, 1989, p. 6-7).

Ao considerar a linguagem como ferramenta de expressão e comunicação de um emissor com um destinatário, Roman Jakobson elaborou um esquema de comunicação constituído por seis fatores: emissário, contexto, mensagem, contato, código, destinatário, os quais resultam em seis funções da comunicação: expressiva, referencial, conativa, fática, metalinguística e poética. Jakobson mostrou que as seis funções consideradas coexistem necessariamente em toda mensagem, mesmo se o seu peso respectivo é variável de um enunciado para outro, em função da situação. Essas seis funções podem ser encontradas tanto no texto linguístico quanto no gesto corporal e na imagem considerada como texto ou discurso. Por serem figuras de retórica, pois visam influenciar o destinatário, elas trazem uma contribuição significativa às teorias da enunciação. 
Nessa linha, Louis Marin indica gestos e indícios corporais que acompanham a fala e reforçam assim as funções elencadas por Jakobson. Veremos que podem ser estendidos, mediante alguma adaptação, a todo tipo de linguagem ou enunciação. Por exemplo, a função expressiva aparece em signos que manifestam as disposições íntimas e as emoções do locutor ou enunciador: uso de interjeições, tom de voz, expressão do rosto, gesto acompanhando a fala, piscar de olho, manifestações involuntárias como o suor ou o tremor. A função conativa é a região dos efeitos do discurso no destinatário da mensagem, da pragmática da linguagem: maneiras de dizer, com tom de voz e mímicas do rosto e do corpo, que visam a "posicionar" o ouvinte numa atitude específica de escuta e a forçar ou manipular sua crença, sua persuasão, sua convicção própria.

A função referencial, denotativa ou cognitiva define a orientação da mensagem verbal para o contexto, o referente. Um exemplo é o gesto de indicação (deixis) manifestado pelos pronomes demonstrativos. O gesto de indicar só pode ser efetuado a partir de uma orientação global do corpo e dos olhos na direção do objeto indicado. O objeto indicado é o objetivo possível de uma ação que o gesto antecipa. Ele estabelece também um destinatário do gesto, como sujeito co-percebendo o mesmo objeto, co-agindo sobre ele virtualmente. No caso da imagem a função denotativa pode estar presente na mensagem linguística constituída pelo título.

A função fática visa a acentuação do contato entre locutor e alocutário (ou destinatário). Trata-se do processo semiótico característico do gesto, da postura ou da atitude do corpo no estabelecimento ou na interrupção do contato entre dois locutores. Por exemplo: apertar a mão direita do outro; gesto de saudação ao levantar o chapéu; manifestações corporais e gestuais estudadas pela proxêmica, ramo particular da semiótica cuja campo é a estruturação significante do espaço humano (ex. distanciamento social na pandemia). ${ }^{1}$

A função metalinguística é dificilmente aplicável aos movimentos do corpo, mas veremos que pode haver uma metalinguagem das imagens. $\mathrm{Na}$ função poética, a linguagem pode se tornar gesto e corpo sensível, por exemplo, na caligrafia, e, inversamente, o corpo e o gesto podem se tornar poema, seja como pele, superfície e suporte de inscrições, de marcas ou

\footnotetext{
1 A proxêmica é o estudo do espaço de proximidade ou distância entre indivíduos, nomeadamente do ponto de vista comportamental, cultural ou social (Dicionário Priberan de português).
} 
de traços que desenham o olho, oferecem ao olfato e ao tato os jogos da sedução, como na arte da maquiagem, dos perfumes e unguentes, das pinturas corporais, da tatuagem, e até nas figuras da dança (MARIN, 2019).

Segundo Gian Maria Tore, a "enunciação” é uma das chaves para compreender e explicar o mundo na perspectiva do signo, a partir do "entredois" ou da mediação entre o ponto de vista biopsicológico individual, e o ponto de vista propriamente social, mediação que podemos chamar de "o simbólico, o significante, ou o semiótico". A enunciação é um verdadeiro dispositivo conceptual, que complexifica o nosso olhar sobre os fenômenos (TORE, 2016, p. 433-434). Por outro lado, a enunciação é o lugar da reflexividade prática. "Enunciação" indica, de um lado, um processo, uma prática que se efetua, e, do outro, o modo sensato com que ela se efetua, sua reflexividade profunda. Pois, a enunciação sempre volta reflexivamente sobre si mesma. Ela problematiza seus próprios aspectos, por meio de "marcas" ou signos, porém, não há signo enunciativo em si: todo signo pode se tornar tal, tornar-se espaço de subjetivação, dependente da abordagem ou da situação (TORE, 2016, p. 446-447).

Segundo Tore, além da linguagem articulada, é possível estudar a enunciação no filme, nas imagens, nos gestos, que podem também indicar uma subjetivação, uma assunção, uma indexação, um estilo, ou uma retórica. ${ }^{2} E$ E que estamos no campo da pragmática da experiência, da construção da situação, da moldagem do real segundo certos limites e orientações, campo no qual se colocam no mesmo plano palavra e gesto, linguagem e comportamento, signos verbais ou visuais (TORE, 2016, p. 439, 443-445).

\section{A enunciação enunciada na imagem}

Foi Jacques Fontanille (1989) que lançou o desafio da transposição do conceito de enunciação para o campo do visual e do audiovisual. A partir daí, para a semiótica, a questão da enunciação se tornou o ponto de partida de toda análise de imagens, não apenas na sua versão "restrita" (a enunciação enunciada), mas também na sua versão "estendida" - que abrange os contextos de produção das imagens assim como os domínios ou estatutos

\footnotetext{
2 Para Fontanille (1989, p. 8), “a interpenetração atual dos diversos modos de expressão e a troca permanente das formas de discurso entre as diversas artes nos impõem, de fato, um percurso simultâneo do texto verbal, do texto pictural e do texto fílmico. Essa intertextualidade formal das formas discursivas deve ser levada em conta pela própria teoria".
} 
que a tornam inteligível (arte, ciência, direito, religião etc.). A "enunciação estendida" - por exemplo nos trabalhos de análise do discurso de Dominique Mainguenau - amplia os limites das explorações, incluindo a descrição da cena da enunciação, da situação de comunicação e dos seus componentes (os protagonistas do discurso, as circunstâncias espaço-temporais, as condições da produção/recepção, o contexto histórico e cultural, as determinações genéricas e socioletivas ${ }^{3}$ ). A semiótica tratará da enunciação estendida ao ligar os estatutos das imagens (artísticas, científicas, políticas) às formas simbólicas das suas instituições, tais como museus, laboratórios, à imprensa, a suas práticas de produção, de exposição, de valorização, e aos objetos que as "suportam": display, telas etc.

Seguindo os trabalhos de Maria Giulia Dondero, vou me limitar à análise da enunciação enunciada (pessoa, espaço, tempo), pela qual a subjetividade está inscrita na imagem. Trata-se de analisar o enunciado visual a partir do lugar onde a imagem foi concebida e a partir do olhar do observador. A enunciação enunciada será assim uma ferramenta permitindo estudar os modos como os valores e as ideologias estão encarnados por enunciados visuais.

A enunciação pode mesmo ser transposta para o campo visual? Existe uma língua visual, com um repertório coletivo de formas estabilizadas no uso e de suas possíveis combinações, e uma verdadeira gramática dos traços em pintura - e nas imagens em geral - (cores, linhas, formas), como foi sustentado por membros do grupo $\mu ?^{4}$ Ou será que cada imagem possui o seu próprio sistema de valores? Também não há regras "sintáticas" universais para a combinação das unidades, como na linguagem natural. A autora propõe, então, uma posição mediana entre a opção segundo a qual existe uma língua visual universal e a opção que concebe cada imagem como um micro-código dotado da sua própria micro-gramática: existiriam diversas línguas visuais, segundo os estatutos aos quais as imagens pertencem (arte, ciência, direito, religião etc.), e também diversas sub-línguas dentro de cada estatuto, distinguindo-se segundo as épocas e as tradições (Cf. DONDERO, 2016b, p. 241-245).

Socioletivo diz respeito ao socioleto. Na linguística, um socioleto é a variante de uma língua falada por um grupo social, uma classe social ou subcultura. Nisto, diferenciase do idioleto, que é a forma de uma língua peculiar a um indivíduo. O socioleto também é diferente do dialeto, que é uma forma de falar peculiar a uma certa área geográfica (Wikipédia).

4 Em outro artigo, a autora dá o exemplo de Paul Klee, que concebeu a produção pictural como uma performance, usando um alfabeto de traçados disjuntos e repetíveis, a partir do modelo da notação em música (DONDERO, 2017, p.196). 
Resultado da "tomada de palavra" ou "tomada de iniciativa" objetivada num suporte, o enunciado é entendido como totalidade significante, produzida por um ato enunciativo ou por um gesto de projeção, isto é, de debreagem, ${ }^{5}$ o qual assegura limites e fronteiras ao enunciado (como o quadro no caso da pintura ${ }^{6}$. Desse modo, os enunciados podem ser analisados a partir do estudo das relações entre formas, cores e posições, em vista de compreender a construção do ponto de vista e de prever a posição que o observador está supostamente ocupando, seja ela espacial, pragmática, cognitiva ou passional. De certo modo, o enunciado prescreve ao intérprete uma tomada de posição, percursos do olhar, assim como um conjunto de valores a serem compartilhados. No caso da imagem, a enunciação não diz respeito ao dizer, mas a um fazer corporal, desdobrado em fazer da produção (pintar, fotografar, desenhar etc.) e fazer da observação (contemplar, olhar, apreender etc.).

O historiador da arte e semiólogo Louis Marin, já mencionado, esclareceu a diferença entre enunciação enunciada e ato enunciativo através do funcionamento dos quadros religiosos. Segundo ele, as Anunciações italianas simbolizariam a correspondência entre a estrutura de comunicação do segredo da Encarnação de Deus e a estrutura da teoria da enunciação. Como base do evento singular da aparição de um enunciado, a enunciação enquanto ato é um "incognoscível” das ciências da linguagem. Só pode ser acessado indiretamente, através de marcas, traços ou indícios deixados nos enunciados empíricos: de certo modo, a enunciação se manifesta enquanto sempre irremediavelmente oculta e inapreensível, do mesmo modo que o segredo no caso da Anunciação. Por exemplo, a Anunciação de Domenico Veneziano (1445-1450) mostra que o segredo da Anunciação é contado apenas no eixo da história, da esquerda para a direita, na terceira pessoa (o anjo Gabriel e Maria são visíveis de perfil: estão excluídos o acesso ao seu olhar e a instauração de um diálogo): logo, é impossível penetrar este segredo no eixo perspectivo, nem no eixo da penetração do observador delegado (a porta) na profundidade do quadro (Cf. MARIN, 1989). Em suma, na enunciação enunciada, só temos acesso aos traços da comunicação, pois o ato dessa

GREIMAS, A. J.; COURTÉS, J., 1989, p. 95-98.

6 O fechamento fornecido pelo quadro funciona como um microssistema linguageiro que nos permite identificar centros da atenção, as múltiplas relações entre o centro e a periferia, os equilíbrios entre os diversos planos em profundidade, a economia das forças de direção da luz etc. 
comunicação/revelação ficará para sempre inapreensível (Cf. DONDERO, 2016b, p. 246-247).

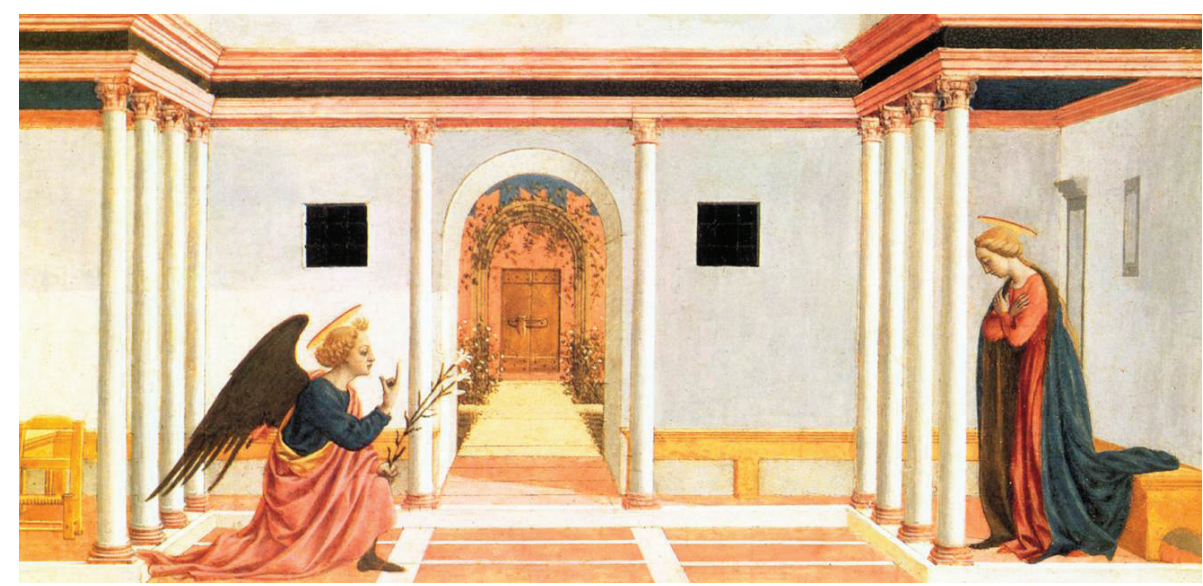

Domenico Veneziano (1410-1461) Annunciazione (cerca de 1445) https://it.m.wikipedia.org/wiki/File:Annunciation (predella 3), fitzwilliam_museum,_Cambridge.jpg. Acesso em 19/07/2021.

No discurso visual, todo ato de enunciação diz respeito a uma tripla "debreagem": actancial (pessoal), temporal e espacial. Em primeiro lugar, a debreagem da pessoa diz respeito ao sistema dos olhares. Os sujeitos pintados ou fotografados de perfil apresentam uma atitude de "terceira pessoa", como, por exemplo, nos quadros históricos, nos quais os acontecimentos se desenrolam sem interpelar o observador - é o caso da imagem acima. Ao contrário, o retrato - quando os sujeitos se mostram de frente e nos interrogam com o olhar - encena o simulacro de uma relação dialógica simétrica e conjugada no presente.

Em segundo lugar, é possível representar o tempo e a narratividade, a duração, na imagem fixa? A debreagem temporal costuma ser significada pela disposição das figuras nos diversos planos em profundidade. A trajetória das forças (luz, formas etc.) sai do presente, manifestado no primeiro plano, até o que está longe no tempo, na profundidade, ou, no sentido inverso, a partir da profundidade, na direção do observador, isto é, o agora do ato de observação. O maior desafio é demonstrar que a transformação narrativa, que envolve necessariamente a extensão temporal, pode ser suportada por uma imagem única (Cf. DONDERO, 2016b, p. 247-248; 2020b, p. 27-32). A maioria dos estudos semióticos nega a 
possibilidade de expressar a temporalidade numa imagem fixa. Ao contrário, o grupo $\mu$ afirma que a cronologia possui também, como a construção do espaço, um ponto de vista ou, melhor, um ponto de apreensão. É o caso da visão desfocada, borrada, embaçada ou distorcida, que pode representar visualmente os estágios sucessivos de uma ação, como o andar ou a queda de um homem, o voo de um pássaro ou o transporte de um objeto: um corpo humano representado obliquamente pode significar uma queda, uma bola implica em rolar, uma faca em cortar.

Uma outra técnica diz respeito ao momento da elaboração que tornaria o observador capaz de ver nos signos plásticos uma sequência narrativa. Um exemplo pode ser encontrado na superposição de uma camada de pigmentos, presente em numerosas pinturas abstratas ou figurativas. A temporalidade será então tornada presente como vestígio do ato enunciativo. Em suma, teríamos aqui mais um passo na direção de reconhecer o visual como uma linguagem que pode estabelecer a articulação do sentido sem recorrer à linguagem verbal, sendo governada por relações de estabilização de forças em formas e por relações de dissipação de formas em forças.

Em terceiro lugar, a debreagem espacial cobre a questão da perspectiva. A perspectiva, ou o ponto de vista a partir do qual algo é desenhado, é sempre um lugar de saber, o lugar a partir do qual o enunciador tem a visão das coisas e a oferece ao espectador ou enunciatário, por meio das seleções, focalizações e distorções da visão. O saber que circula entre o enunciador e o enunciatário não é exclusivamente cognitivo, mas possui determinações passionais e pragmáticas. O enunciador, na imagem, "prepara" o lugar do espectador, que deverá ocupá-lo se quiser reconstruir o percurso da significação. É claro que cada imagem encarna uma relação intersubjetiva possiviel, e não necessariamente atestada. A relação entre a atividade de produção do enunciador e a vontade de conhecer do enunciatário pode ser conflitiva, pois as imagens podem modular a presença e até negá-la. Elas nos colocam muitas vezes frente a situações de "luta pela visão" (DONDERO, 2016b, p. 249). 


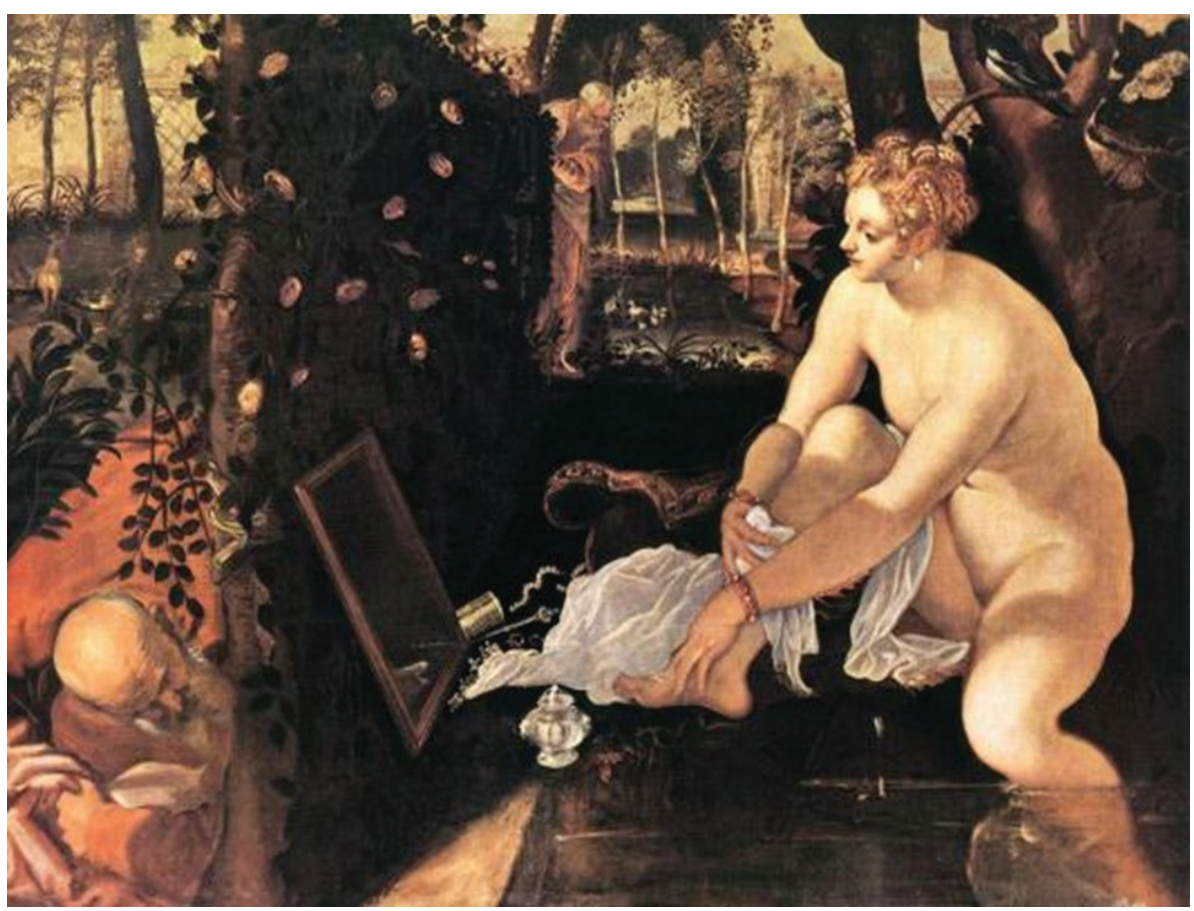

Tintoretto: Suzana e os anciãos.

bttps://virusdaarte.net/tintoretto-suzana-e-os-velhos. Acesso em 27/07/2021.

É o caso do quadro Suzana e os anciãos, do Tintoretto, que nos apresenta uma luta entre os olhares dos anciãos, que procuram ver Suzana tomando banho; de Suzana, que se proteja dos olhares de outrem pela concentração no espelho e pelo posicionamento entre as árvores e a cerca; e do simulacro dos olhares dos espectadores, que hesitam entre a visão oferta pela perspectiva do corpo nu de Suzana e o modelo do olhar oferecido pelos anciãos, voyeurs indiscretos e a priori excluídos do espetáculo da nudez feminina. Os anciãos aparecem como observadores delegados, substitutos do espectador no quadro. Além de colocar para nós uma questão ética a respeito do ver e do olhar, a imagem encena a negação do papel da imagem e do seu estatuto: o de ser plenamente oferecida aos olhares (Cf. DONDERO, 216b, p. 248-250). Esse tipo de negação não diz respeito apenas à enunciação enunciada, mas ao fato de que a imagem, produzida para ser contemplada, mostra algo que não deve ser visto (proibido ou secreto), e que nega assim sua própria práxis enunciativa (Cf. DONDERO, 2016a, p. 25-28). 
O esquema da modalização cognitiva do espaço pode ser resumido num quadrado semiótico representando as relações de contradição e de contrariedade, que podem ser lidas como relações lógicas, mas também como relações de transformação narrativa:

"A exposição (regime contratual da visão: não poder não observar/fazer saber) caracteriza tudo o que se dá a ver ao observador, que é suposto querer olhar; nesse caso, o enunciador não tem nada para esconder (DONDERO, 2016b, p. 251)." Por exemplo, num retrato que representa uma personagem vista de frente, bem iluminada e centrada.

A inacessibilidade (regime polêmico da visão), quando o observador não pode observar e o enunciador oculta o seu saber (fazer não saber). "Caracteriza muitas vezes a pintura das visões místicas, onde a visão de Deus pelos santos nos é ocultada pela própria força divina (Ibid., p. 252)."

A obstrução (regime da discórdia, não contratual: poder não observar, não fazer saber), caracteriza "tudo o que é camuflado, dificilmente apreensível, incompleto, e que funciona como uma negação da exposição: é muitas vezes o caso de imagens que mostram objetos distantes, deslocados do centro da imagem ou vistos de costas (Ibid.)."

A acessibilidade (regime da conciliação), "caracterizada pelo "poder observar" do observador e por um "não fazer não saber" da parte do enunciador. Diz respeito a tudo que se deixa aperceber, entrever, toda falha no obstáculo, que amplia os limites do campo visual (espelhos, reflexos, portas ou cortinas abertas) (Ibid.)."

Como ilustração do esquema, vejamos a função da cerca na imagem acima:

ela funciona como barreira contra os olhares indiscretos, mas os lados do triângulo perspectivo construído ao longo da cerca permitem a infiltração dos olhares de um lado e do outro, através de lacerações na fronteira de separação entre a zona de intimidade de Suzana, constituída pelas projeções do espelho e da cerca, e o exterior da zona exclusiva, aquela dominada por interstícios nos quais penetram os olhares indiscretos dos anciãos (DONDERO, 2016a, p. 26).

"Suzana usa a cerca como lugar de proteção contra os olhares de outrem, conjugando um poder se olhar e um querer não ser vista, enquanto para os anciãos, a cerca funciona como objeto lhes permitindo se esconder: um poder olhar e um não dever ser vistos, (Id. p. 27)" isto é, há duplicidade modal da cerca. "O espelho, do mesmo modo que a cerca, constrói modalidades 
contraditórias da visão, de fechamento e abertura (Ibid.)." "Em suma, a cerca e o espelho podem se definir como lugares de suspensão (e de participação) entre configurações de forças em oposição, entre sombra e luz, fechamento e abertura, ou melhor, entre não fechamento e não abertura (Id. p. 28)." Assim, a negação é exemplificada topologicamente por contradições de forças que se enfrentam e se equilibram. Pois, a negação articula e multiplica os percursos interpretativos possíveis em concorrência entre si.

As relações entre os elementos da imagem podem também ser analisados em termos de forças e gestualidades emocionais na imagem. Baseada na noção de sintaxe figurativa (Fontanille), a autora aborda o caráter textualizado, ou mesmo estabilizado das forças em formas visuais. É a força que resulta do processo de produção criativa e das suas técnicas, processo constante de instauração das matérias que são trabalhadas para lhes dar uma forma, e que se inscreve na obra acabada. É preciso conceber as formas representadas numa imagem como o resultado de forças implicadas em cada um dos componentes seguintes:

o suporte material que recebe as inscrições, por exemplo, a tela: ele dispõe de forças autônomas, como as qualidades físicas da madeira, do plástico etc. (resistência, elasticidade, dureza - que já são forças em potência); um suporte formal, isto é, a organização selecionada como pertinente no seio do suporte material em vista do ato de inscrição; um aporte, isto é, uma matéria - o componente cromático, por exemplo - que permitirá a inscrição de traços e linhas sobre um suporte; o geste de inscrição propriamente dito, isto é, o ritmo pelo qual as inscrições puderam ser depositadas e trabalhadas sobre o suporte, ou a ancoragem espaço-temporal do ato de enunciação (DONDERO, 2020a, p. 4).

Encontramos aqui a questão do médium, "que não deve ser estudado apenas enquanto dispositivo técnico, mas também enquanto resultado da tradição, da institucionalização e da estratificação das práticas de transmissão e interpretação dos corpora textuais (DONDERO, 2012b, p. 20)." É o estatuto, isto é, o papel institucional que uma imagem assume, que pode determinar as configurações de sentidos produzidos pelo médium. "A semiótica do rastro de Fontanille (2004) considera com razão as formas como sempre 'ainda impregnadas' pela 'maneira de fazer' e por uma atividade corporal. É que a figura entendida como corpo possui uma estrutura e um invólucro que mantêm as marcas da sua instanciação (memória discursiva) (DONDERO, 2012b, p. 23). 
Segundo René Thom, as marcas ou impregnações (prégnances) são forças investindo um centro, e elas são vinculadas às emoções. A essência da arte é realizar uma junção permanente entre impregnações físicas manipuláveis (a luz, por exemplo), enraizadas nas matérias do mundo e nossas próprias impregnações ou qualidades subjetivas (a alegria, por exemplo), sejam elas biológicas, conceituais ou institucionalizadas. A força da imagem se propaga também rumo ao exterior,

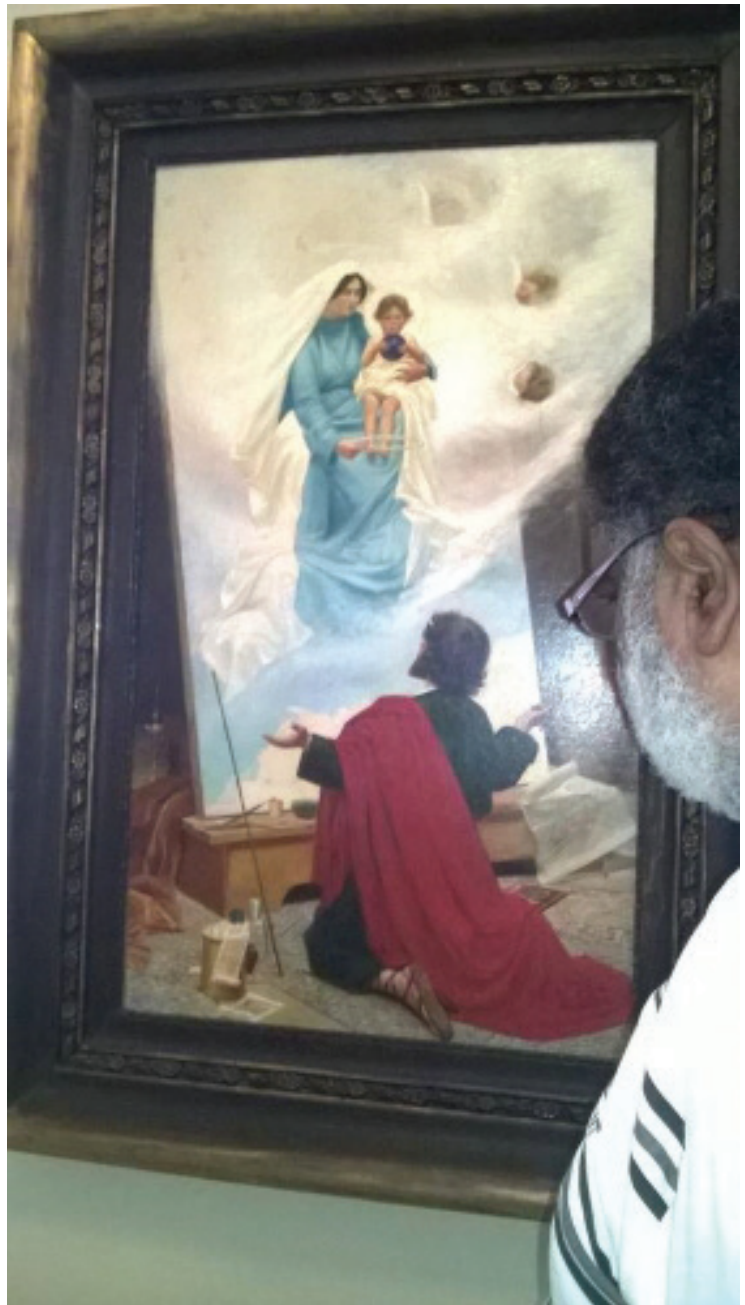

Maria Antonieta Feio: A Virgem Maria e são Lucas. Museu de Arte de Belém, PA.

Acervo do autor. graças ao contorno e ao quadro, na forma de uma espécie de aura, que preenche todo o seu entorno, investindo outras imagens e o meio ambiente. Essas forças demandam uma resposta da parte do observador: são as práticas interpretativas. De fato, cada força agindo no quadro pede um certo tipo de reação e todo ato de observação é narrativo, nem que se trate apenas de acompanhar com os olhos a transformação da intensidade luminosa num quadro. (THOM,1983, p. 8, apud DONDERO, 2020a, p. 5-7).

Pelo que foi dito até agora, confirmase a existência de uma metalinguagem visual, correspondendo à quinta função de Jakobson e Marin. Para Maria Giulia Dondero, a linguagem visual produz "dobras", esquemas, finas películas 
em si mesma, que, ao se destacarem do representado, permitem perceber que a imagem é estratificada, estruturada. É difícil dizer se se trata de um aparelho formal da enunciação, que se repete em cada imagem, ou de um nível organizador próprio de cada plano de expressão, diferente em cada imagem. A enunciação visual enunciada deve ser entendida, ao mesmo tempo, como lugar da comunicação intersubjetiva inscrita na imagem (função conativa, referencial ou fática) e como lugar onde a imagem problematiza, de modo mais ou menos explícito, o seu ato produtivo, por meio de um desdobramento (por espelho, quadro no quadro, porta etc.) que simularia esse ato de produção e observação (função metalinguística).

Nem sempre é possível distinguir as duas acepções, pois há muitos casos em que fica difícil distinguir entre o que pertence de direito ao sistema da comunicação intersubjetiva e o que pertence à reflexão da imagem enquanto desdobramento do seu ato de enunciação. Uma primeira possibilidade é a enunciação enunciada como tematização da enunciação no enunciado (função metapictórica). Por exemplo, no quadro de Jan Gossaert, São Lucas evangelista pintando a Virgem (cerca de 1520): o ato de pintar é diretamente representado. Há um desdobramento do quadro, que mostra uma debreagem em ato representada dentro do quadro (a produção pictural) e o resultado dessa debreagem (o quadro pintado dentro do quadro). ${ }^{7}$ No quadro visto pessoalmente no Museu de Arte de Belém, PA, A Virgem Maria e São Lucas, de Maria Antonieta Feio, São Lucas contempla o quadro da Virgem que acaba de pintar. A nossa foto acrescenta o plano do observador vivo contemplando o quadro do museu, desdobrando a metalinguagem.

Em As Meninas, de Velasquez (1656), o pintor olha o observador nos olhos, em primeira pessoa, como se estivesse pintando os espectadores como segunda pessoa no diálogo enunciativo (função fática). Um simulacro de observador está presente pelo espelho colocado de frente, no fundo da oficina. Além do diálogo, há uma reflexão sobre o movimento corporal do pintor que, já sendo actante do fazer, torna-se também actante do olhar. Há também no quadro uma verdadeira reflexão teórica sobre o enquadramento, através da porta, da janela, do espelho, da tela, das cortinas e dos quadros representados, que são identificáveis como embreadores/enunciadores, mas também como dispositivos reflexivos próprios da pintura (função metalinguística ou metapictórica) (Cf. DONDERO, 2016b, p. 253-254). 7 Por causa da falta de espaço, é impossível reproduzir todas as obras citadas. O leitor as
encontrará sem dificuldades na internet. 


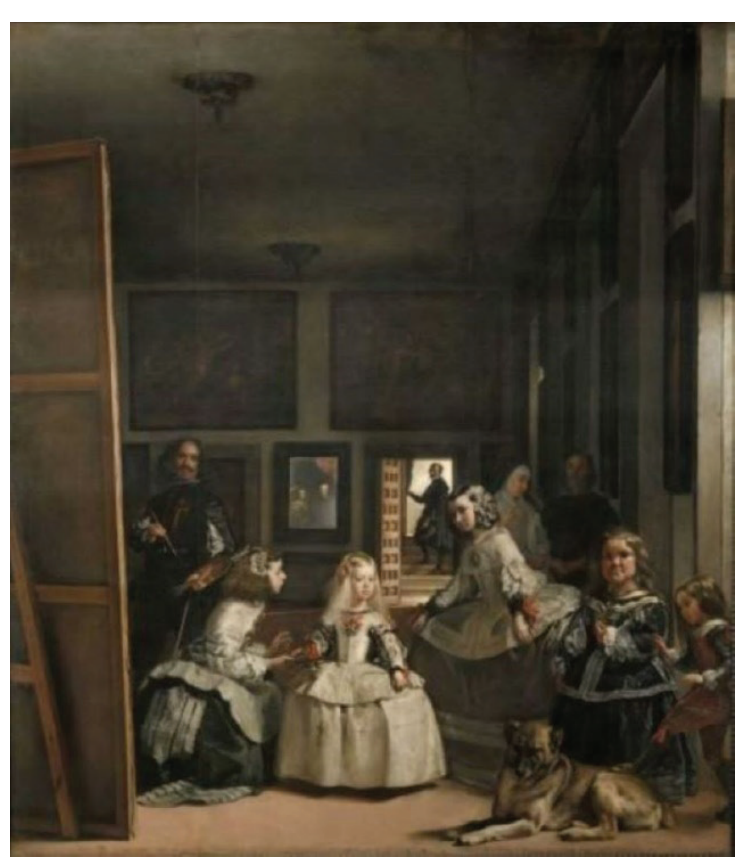

Diego Velásquez: Las meninas.

https://replicarte.com.br/products/las-meninas-diegovelazquez. Acesso em 27/07/2021.
A técnica enunciativa pode também ser encarnada no enunciado pictural pela textura. Pode aparecer em quadros abstratos, semifigurativos e figurativos. A autora toma o exemplo do Campo de trigo com corvos, de Van Gogh. A questão enunciativa dos embreadores relacionase diretamente com a técnica mostrada, ou com as relações entre suportes e aportes, que se manifestam entre o tipo de tratamento da tela e o ritmo dos movimentos do pincel. "A textura é o lugar mais emblemático da manifestação da subjetividade na linguagem

da imagem: é o lugar onde o corpo inteiro do produtor deixa os vestígios da sua pegada única, da sua identidade pronominal, mas é também um retrato perfeito do ato enunciativo em si mesmo (Id., p. 256)."

\section{A enunciação na pintura religiosa}

Quais são os efeitos de sentido que os textos picturais geram quando são supostos representar não apenas o invisível, mas também a transcendência? Podemos encontrar a resposta pelo estudo das técnicas produtivas e das práticas interpretativas, apresentadas no item anterior. Esse estudo vai nos permitir abordar a questão da temática religiosa na pintura. Para a autora, o caráter sagrado deriva de um ato não repetível, o gesto sensorial motor do pintor, que se assemelha à experiência do sagrado (epifania). Aliás, o próprio pintor, sobretudo a partir do Renascimento, participa da sacralidade da sua ação (DONDERO, 2012b, p. 24, 26). 
É preciso introduzir aqui uma distinção entre o religioso e o sagrado: a dimensão do religioso diz respeito à institucionalização do questionamento humano sobre as escolhas morais da conduta cotidiana, assim como sobre a fé e o futuro radical; a dimensão do sagrado diz respeito a um questionamento individual sobre o que determina o valer dos nossos valores e o caminho que cada um pode empreender para dar sentido à própria vida. Assim, a religião é um modo institucionalizado de aceder ao sagrado. Nesse caso, a oposição entre valores se funda sobre o eixo bem $/ \mathrm{mal}$; ao contrário, no domínio do sagrado, ela se funda sobre o eixo sensato/insensato. O sagrado diz respeito à luta contra o insensato da nossa vida, luta pela qual aceitamos de viver ou de morrer. $\mathrm{Na}$ religião, as condutas de ação e os valores são determinados a priori pela instituição, ao passo que no sagrado, a busca pessoal e única se funda numa delegação contínua das questões e uma renúncia às respostas definitivas.

A partir daí, é possível mostrar a relação entre a representação da sensorialidade e as dimensões das experiências tanto religiosas quanto relativas ao sagrado em imagens modernas e contemporâneas. De modo geral, o campo do religioso pode reivindicar várias tradições iconográficas estabilizadas por temáticas bem precisas, como a representação de cenas bíblicas, ao passo que o "domínio" do sagrado não possui nenhuma tradição iconográfica nem prescrição: pode emergir e ser significado por todo tipo de temática, tão religiosa quanto profana.

Podemos encontrar representações visuais do religioso e do sagrado encenando os diversos tipos de sensorialidade. Para a sensorialidade motora, podemos mencionar a estética do borrado ou do embaçado em Francis Bacon. O borrado permitiu, muitas vezes, a representação dos diferentes graus do real: as visões fantasmáticas, os desejos, os sonhos, os pensamentos. ${ }^{8}$ No caso do tato, temos a encenação das feridas do Cristo e da provação da crença e da fé pela vontade dos fiéis de tocar para verificar. ${ }^{9}$. No caso do olfato, o campo sensorial se constrói pelo desdobramento de invólucros corporais através de camadas de exalação em forma de nuvens, que se deslocam para outros corpos ao invadi-los. Por exemplo, vejamos as pétalas de rosas portadoras de perfume na representação da assunção da virgem por Nicolas Poussin, numa dinâmica expansiva e ascendente (Cf. DONDERO, 2013, p. 80-88)..$^{10}$

\footnotetext{
8 Ver Francis Bacon: Estudo para um papa VT.

9 Por exemplo, no quadro $A$ incredulidade de São Tomé (1603), do Caravaggio.

10 Ver: Nicolas Poussin: Assunção de Nossa Senhora.
} 
Ao focar a dimensão da sensorialidade visual, reencontramos a questão da negação, aplicada agora à figuração religiosa (função metalinguística ou metapictórica). Trata-se da dificuldade inerente à pintura religiosa ocidental para representar algo irrepresentável: como representar o que é, por excelência, negado como representável? Na figuração medieval, Deus e a transcendência são representados por meio de imagens que são negações de negações, possivelmente tentativas de atenuar a força da negação teológica originária.

Daí resultam diversos graus de afirmação, começando pelo mais fraco: em primeiro lugar, pode-se tomar como tema da imagem a própria não representabilidade da transcendência, por exemplo, significando a imagem do Cristo por letras constituindo um monograma. ${ }^{11}$ Esse tipo de representação afirma a impossibilidade de figurar a divindade de uma maneira outra que simbólica e/ou ornamental. A escrita simbólica objetivada num suporte manifesta em positivo a negação do representável icônico. É uma afirmação por desvio: aceita-se o interdito teológico e escapa-se do problema linguageiro.

Um segundo grau de afirmação é a abstração como resposta não afirmativa à negação originária. Por exemplo, na Trindade extática, tirada dos cânticos de Rothschild (cerca de 1300, Flandres ou Renânia). A imagem, produzida num meio influenciado pela teologia negativa, representa a unidade circular de Deus, tornando as três pessoas totalmente invisíveis. Expressase a negação de poder alcançar uma representação verdadeira da divindade. O espectador é obrigado a superar a cultura da mimesis. A estranheza da imagem em relação com todas as coisas conhecidas induz a imaginação de algo que supera tudo o que conhecemos (Cf. DONDERO, 2016a, p.30-32).

O terceiro grau, mais forte, é a negação da figurabilidade, ao apresentar seres do mundo da vida cotidiana que, pela mistura de naturezas (homem/animal, homem com vários rostos), tornam-se criaturas monstruosas. "A figuração não abstrata da experiência mística é uma negação da impossibilidade de figurar, talvez uma negação da negação da representabilidade (Id., p. 32)." Mostra-se que se pode figurar o ser transcendente por meio da negação da composição comum dos seres terrestres. “É uma negação afirmativa, ou uma afirmação no segundo grau, pois ultrapassou a negação originária: o interdito sagrado, a impossibilidade da figuração, a não representabilidade ontológica de Deus (Ibid.)." 11 Por exemplo, Monograma do Cristo em letras vermelhas. In: Raban Maur. In honorem sanctae crucis.
Fulda, cerca 830-850. 


\section{A representação da visão mística no século de ouro espanhol}

O quarto tipo de representação do irrepresentável merece um tratamento especial, a partir do livro de Victor Stoichita: Visionary Experience in the Golden Age of Spanish Art (1995). Trata-se da representação de visões místicas - ou teofanias - agraciando figuras de santos e santas, tratadas na linha da retórica da Contra-Reforma. A função fática, que estabelece um contato direto com o destinatário, e a função conativa, que visa a persuasão dele, estão presentes em todas as pinturas que são produtos da ContraReforma, pois, segundo o Concílio de Trento, os poderes de salvação da Igreja, manifestados pelos santos, são demonstrados pela relíquias e pelas pinturas. Elas são instrumentos para unir os fiéis a Deus. Para que isso aconteça, as autoridades eclesiásticas convidam os artistas a representar santos em êxtase e suas visões para suscitar a participação empática dos fiéis: uma pintura retratando uma visão inspira outra visão. Pois, segundo o Concílio: "O objetivo primordial da pintura é persuadir as pessoas a serem piedosas e submeterem-se a Deus; o seu fim é inspirar nas pessoas a obediência e a fidelidade devidas a Deus (PALEOTTI apud BAROCCHI, 1961, p. 214-215).” Por isso, por exemplo, o Cristo crucificado deve ser representado olhando para cada pessoa que possa estar rezando a seus pés como se ele estivesse falando para essa pessoa, lamentando o fato de estar sofrendo por aquele que reza diante dele. ${ }^{12}$ (Cf. STOICHITA, 1995, p. 67-70).

Victor Stoichita demonstra, na pintura de visões, a essência metalinguística desse tipo de pintura religiosa, que tem como tema as diferentes encenações da relação entre olhar humano e visão supra-humana. A representação indireta ou metalinguística da visão, pela narração da experiência, permite filtrar, de certo modo, o aspecto "selvagem" e perigoso do êxtase místico. Portanto, os quadros são sempre divididos em dois planos verticais representando dois mundos separados: o do visionário e o da visão. Trata-se de duas zonas distintas, mas intercomunicáveis: uma zona terrestre, uma zona celeste. A técnica comumente usada por pintores da Contra-Reforma, para representar exteriormente a experiência visionária interna, foi colocar o visionário na parte mais baixa da pintura e a visão na parte superior. A função metalinguística se relaciona com a cisão da pintura em duas partes, já que todas as pinturas de aparições são obras que falam

12 Ver, por exemplo, o Cristo de la Clemencia, de Montañés. 
de uma "imagem" (uma visão) com as ferramentas da pintura (imagem que

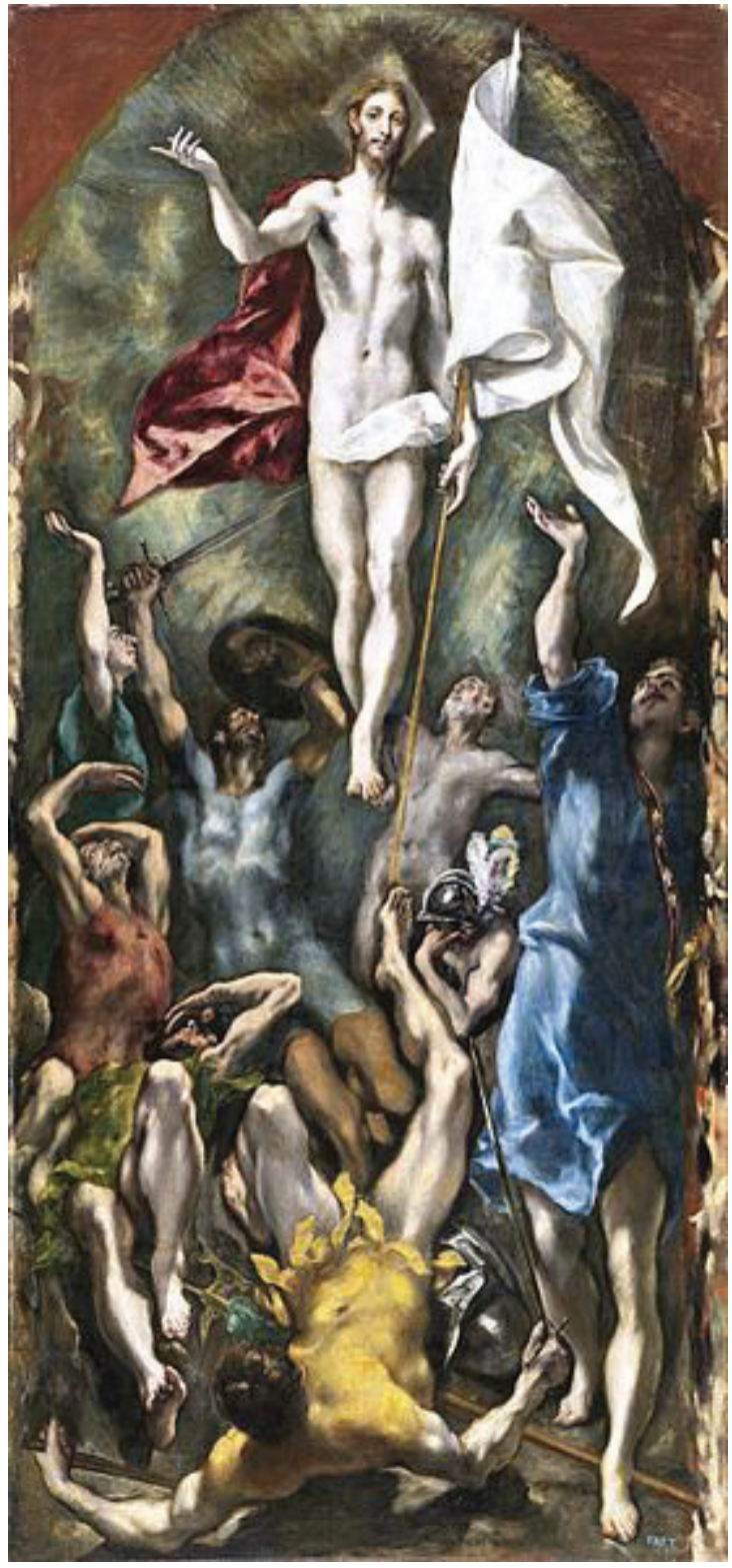

El Greco: A Ressurreição. WGA10530.jpg. Wikipédia.

Acesso em 27/07/2021 fala sobre outra imagem).

A aparição tem sempre um caráter simbólico, pois uma visão é diferente da presença real do Divino assim como é manifestada pelos santos sacramentos. É uma parusia de segundo grau, isto é, irreal, imaginária e, por isso pessoal, privada e, em consequência, incontrolável. Só a representação da representação garante, ao mesmo tempo, comunicação e controle. O problema de unir transcendência e imanência foi assumido pela Contra-Reforma, no sentido de uma dramática verticalização da experiência visionária. Os visionários e as personagens que os acompanham estão geralmente em atitude de oração, atitude preconizada pela igreja para os espectadores (Cf. STOICHITA, 1995, p. 27-32).

De fato, na maior parte dos casos, como na Ressurreição de El Greco, estamos frente a uma representação da representação. Vemos o Cristo, flutuando no ar, 
olhando fixamente para o espectador, isto é, para nós, em vista de nos integrar à pintura. A pintura transforma a cena da Ressurreição (que não foi vista por ninguém) numa cena dramática cujo tema é o confronto visual com o Sagrado. A tensão conecta e separa a parte superior da parte inferior, a terrestre da celeste, a profana da sagrada, o homem que cai do Deus que sobe. Os personagens estão em diversas atitudes contemplativas. A relação entre os dois planos é estabelecida pela mão levantada de dois personagens, que enquadram a cena, e pelos pés do Cristo (STOICHITA, 1995, p. 37-38).

Para mostrar a visão divina, insubstancial, invisível e inimaginável, são adotadas diversas características: cores suaves, para representar uma substância supra-humana; um esplendor banhado numa luz suave e uma perspectiva de distanciamento, com diversos níveis e horizontes. Na visão extática, trata-se de dar forma a uma visão da transcendência que é profundamente íntima, interior - e o que é interior já está a priori excluído do representável em imagem. A estratégia mais poderosa para representar a visão subjetiva da revelação é a da nuvem. A nuvem é o limiar a partir do qual tudo o que se vê escapa do interdito e da impossibilidade de representar o caráter íntimo e não reprodutível da visão extática.

A natureza dinâmica da nuvem, suas constantes metamorfoses, amplificam sua incerteza essencial e fazem da sua contemplação uma atividade que não resulta em nenhum tipo de certeza. $\mathrm{Na}$ Bíblia, a nuvens são instrumentos de revelação. Elas revelam e escondem ao mesmo tempo, ao aceitar o seu estatuto restrito em relação ao invisível. A dialética nuvem/ glória assim como aparece no Êxodo (24, 15-18; 33, 20) é fundamental para todas as experiências teofânicas judeu-cristãs. O próprio Evangelho menciona nuvens que ocultam a visão dos discípulos, nos relatos da Transfiguração e da Ascensão.

Porque o brilho da glória pode cegar, a nuvem a torna paradoxalmente visível ao beneficiário. A nuvem pode criar uma barreira entre o místico e o divino, mas pode também ser o sinal de uma presença. A pintura vê a ambiguidade visual da nuvem como um meio essencial de visualizar o Sagrado. A nuvem se parece, segundo Erasmo, com o "nada" ou o "sonho" por causa da sua falta de substancialidade, que impede que seja representada colorida. Na representação de visões, o raio representa um excesso, ao passo que a nuvem indica uma falta. Juntos, eles são capazes de mostrar o caráter irrepresentável da divindade (STOICHITA, 1995, p. 84-88). 
No quadro de El Greco, São Francisco recebendo os estigmas, Deus é, na visão de São Francisco, representado como uma luz que se esconde atrás de uma nuvem. "A figura da nuvem funciona como limiar entre o que é representável e o que não o é: a nuvem nega a homogeneidade do espaço da perspectiva, pois funciona como borda entre o espaço terrestre e o espaço celeste." A nuvem é enunciada a partir do olhar do santo visionário, como limiar que significa o começo de uma outra ordem do real e de uma sintaxe figurativa diferente. Há um apagamento progressivo das cores, que se tornam as menos corporais possíveis, e a nuvem encarne a retórica do não preciso, possivelmente do aproximativo, pois é esbranquiçada como a tela vazia. "É o lugar da incerteza, do que não tem medida, o lugar do impreciso, até do vago: a nuvem deve ser entendida como negação dos objetos apreensíveis, representados na parte inferior da imagem, onde a visão se prepara (DONDERA, 2016a, p. 34).”

A nuvem é o produto de uma negação da tradição pictural da mimesis que contém em potência todas as formas. É uma figura da negação não apenas porque nega, no nível enunciativo, a possibilidade de dar forma à divindade, até a possibilidade e ver/

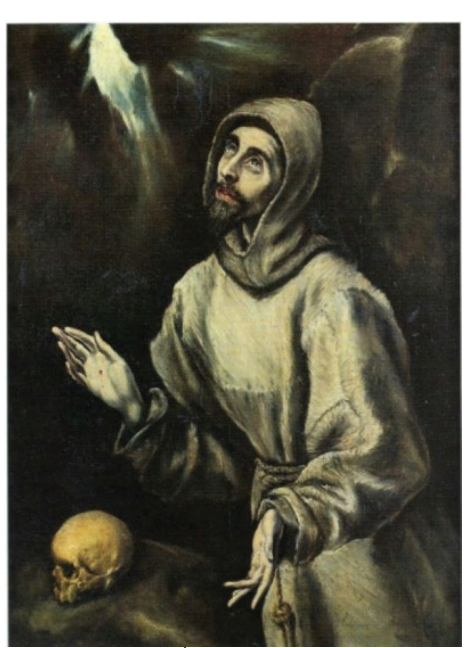

El Greco: Exxtase de São

Francisco com os estigmas.

bttps://pt.wikipedia.org/wiki/ Representações de_São Francisco_de_ Assis_na_obra_de_El_Greco. Acesso em 27/07/2021. representar a divindade, mas, no nível do enunciado igualmente, o esplendor da teofania é deslumbrante e a nuvem permite escondê-la, obstruí-la e, assim, paradoxalmente, revelá-la pela negação do deslumbramento, como podemos observar em A Trindade em glória, do Ticiano (DONDERO, 2016a, p. 34).

Segundo Stoichita, o quadro do Ticiano é uma tentativa revolucionária de criar uma pintura única representando um plano celestial visto a partir da interioridade. O conjunto do conteúdo está flutuando no ar. De fato, a linha do chão é muito pouco visível e a linha do horizonte é apenas uma raia fina na borda inferior do quadro. O enorme plano celestial que ocupa a maior parte do espaço figurativo é visto numa perspectiva reduzida bem 


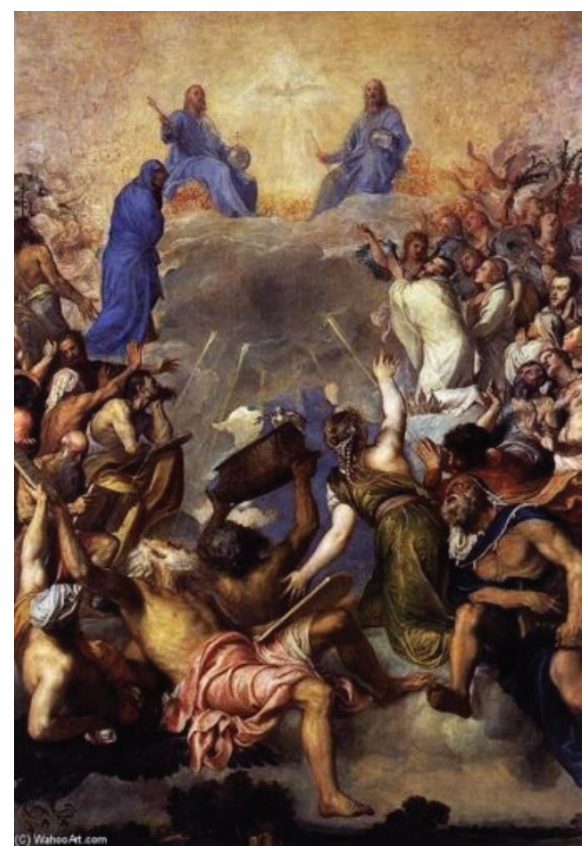

Ticiano: A Trindade em Glória.

WahooArt.com.

Acesso em 27/07/2021.

elaborada. Apesar das figuras serem reduzidas e envolvidas por uma nuvem, com o esplendor da glória, ainda é possível identificá-las. Os três elementos que trazem a maior contribuição ao quadro como um todo (perspectiva, nuvem, luz) estão em estreita relação: os raios, que rasgam a nuvem, constituem a forma octogonal do céu e encontram o seu ponto de fuga na figura simbólica do Espírito Santo. Finalmente, a adoção do ponto de vista rebaixado permite evitar a visão da linha sobre a qual as figuras colocam seus pés na nuvem (STOICHITA, 1995, p. 94).

A respeito de nuvens, há um elemento interessante no quadro do museu de Belém, apresentado acima: as nuvens da visão de São Lucas, com duas figuras de anjinhos, parecem envolver o quadro dentro do quadro, ou até sair dele, o que reforça o caráter metapictórico da representação.

\section{Considerações finais}

Como mostrei no artigo, a enunciação é o ato linguístico, gestual ou imagético, isto é, o evento histórico que constitui, por si mesmo, a aparição de um enunciado. É uma "tomada de iniciativa" pela qual um enunciado no nosso caso, um enunciado visual ou uma imagem - é projetado como totalidade significante num suporte. Todo enunciado inclui, de um lado, um conteúdo representativo e, do outro lado, uma atitude tomada pelo enunciador em relação com esse conteúdo. Temos, de um lado, um processo, uma prática que se efetua, e, do outro, o modo sensato com que ela se efetua, sua reflexividade profunda. É pela enunciação enunciada que a subjetividade está inscrita na imagem. Nela, o sujeito não constrói apenas a significação, mas a assume, adotando um ponto de vista e projetando um observador. 
No caso da imagem, a enunciação não diz respeito ao dizer, mas a um fazer corporal, desdobrado em fazer da produção (pintar, fotografar, desenhar etc.) e fazer da observação (contemplar, olhar, apreender etc.). O caráter sagrado de uma imagem deriva também de um ato não repetível, o gesto sensorial motor do pintor, que se assemelha à própria experiência do sagrado. Desse modo, mostrei como se pode interpretar uma imagem religiosa a partir da teoria da enunciação visual.

Numa outra oportunidade, seria interessante desenvolver as afinidades que existem entre a teoria semiótica da enunciação e as propostas apresentadas pelos representantes da "virada icônica". Como indiquei num trabalho anterior (HIGUET, 218, p. 126-160), para a nova tendência, iniciada por Gottfried Boehm, a ideia de presença chama atenção para a vida dos objetos visuais, que são capazes de agir e de suscitar sentimentos e emoções, de nos afetar pelo seu apelo estético e poético. $\mathrm{Na}$ perspectiva antropológica adotada por Hans Belting, os artefatos visuais estão embutidos em média, que são metáforas para o corpo humano, cuja ausência elas suprem com uma forma diferente de presença. Enfim, para Horst Bredekamp, a imagem não é derivação nem ilustração, mas um médium ativo do processo de pensamento, o que exige que se acrescente a análise das formas e da sua história à procura de informações sobre produção, recepção e efeitos sobre o espectador, para entender os conteúdos visuais. Bredekamp define o "ato de imagem" (Bildakt) em paralelo com o ato de fala, ao ressaltar o papel ativo que a imagem desempenha, no intercâmbio com o observador. Encontramos tudo isso na teoria da enunciação, com a diferença da exclusão da ideia de representação, substituída na virada icônica pela noção de "mostração". Encontramos assim maneiras diferentes de incorporar a subjetividade às obras artísticas, que valeria a pena comparar e confrontar.

\section{Referências}

BENVENISTE, E. Problèmes de linguistique générale, 1. Paris: Gallimard, 1966.

DONDERO, M. G. Les forces dans l'image et les gestualités émotionnelles. SHS Web of Conferences, 81, 03005, 2020a, p. 1-14.

DONDERO, M. G. The Language of Images. The Forms and the Forces. Cham (Suiça): Springer Nature, 2020b.

DONDERO, M. G. La négation dans l'image. Pour une approche énonciative. In: BADIR, S.; DONDERO, M. G. (dir.). L'image peut-elle nier? Liège: Presses universitaires de Liège, 2016a, p. 17-35. 
DONDERO, M. G. Picturing Transcendence. Image and Narrative, Vol. 13, n. 4, 2012a, p. 221-234.

DONDERO, M. G. Le religieux et le sacré vus à travers l'iconographie de l'olfaction. Questions de communication, vol. 23, 2013, p. 79-100.

DONDERO, M. G. L'énonciation énoncée dans l'image. In: COLAS-BLAISE, M.; PERRIN, L.; TORE, G. M. (dir.). L'énonciation aujourd'hui: un concept clé des sciences du langage. Limoges: Lambert-Lucas, 2016b, p. 241-258.

DONDERO, M. G. A enunciação enunciada na imagem. In: ABRIATA, V. L. R.; SALLES, A. C.; SIQUEIRA, J. H. S. de. (org.). Vozes do social: a enunciação visual e sincrética na diversidade das mídias. Franca, SP: Unifran, 2019, p. 15-42.

DONDERO, M. G. Énonciation visuelle et négation en image: des arts aux sciences. Actes sémiotiques, 114, 2011. Disponível em https://www.unilim.fr/actes-semiotiques/2578. Acesso em 16/06/2021.

DONDERO, M. G. L'énonciation visuelle entre réflexivité et métalangage. In: DONDERO, M. G.; BEYAERT-GESLIN, A.; MOUTAT, A. Les plis du visuel. Réflexivité et énonciation dans l'image. Limoges: Lambert-Lucas, 2017, p. 192-206.

DONDERO, M. G. La sémiotique face à la médiation du discours religieux. Semiotica 191 - 1/4, 2012b, p. 19-36.

DUCROT, O. Énonciation. In: Encyclopaedia Universalis, Paris: Universalis, 2019, DVDRom.

FONTANILLE, J. Les espaces subjectifs. Introduction à la sémiotique de l'observateur (discours, peinture, cinema). Paris: Hachette, 1989.

FONTANILLE, J. Soma e Séma: Figures du corps. Paris: Maisonneuve et Larose, 2004.

FUCHS, C. Énoncé, linguistique. In: Encyclopaedia Universalis. Paris: Universalis, 2019a, DVD-Rom.

FUCHS, C. Fonctions du langage. In: Encyclopaedia Universalis. Paris: Universalis, 2019b, DVD-Rom.

FUCHS, C. Linguistique: Théories, In: Encyclopaedia Universalis. Paris: Universalis, 2019c, DVD-Rom.

GREIMAS, A. J.; COURTÉS, J. Dicionário de semiótica. São Paulo: Cultrix, 1989.

HIGUET, E. Interpretação das imagens na teologia e nas ciências da religião. In: NOGUEIRA, P. A. S. (org.) Linguagens da religião. Desafios, métodos e conceitos centrais. São Paulo: Paulinas, 2012, p. 69-106.

HIGUET, E. Contribuição dos estudos de cultura visual para as Ciências da Religião. In: SILVEIRA, E. S. (org.) Como estudar as religiões: metodologias e estratégias. Petrópolis: Vozes, p. 126-160.

HIGUET, E. Métodos semióticos na cultura visual: a semiótica visual. In: MENDONÇA, K. M. L.; RENDERS, H.; HIGUET, E. A. (org.). Religião e cultura visual no Brasil. Desafios e métodos. Belém: EDUEPA, 2020, p. 220-243. 
JOSGRILBERG, Rui S. Que é um texto? - A vida e o mundo nas tramas de sentido de um texto. Revista Internacional d'Humanitats, 39, p. 87-94, jan.-abr. 2017.

MARIN, L. Corps. Corps et language. In: Encyclopaedia Universalis. Paris: Universalis, 2019, DVD-Rom.

MARIN, L. De la représentation. Paris: EHESS, 1994.

MARIN, L. Opacité de la peinture. Essais sur la représentation au Quattrocento. Paris: EHESS, 2006.

PALEOTTI, G. Discorso intorno alle immagini sacre e profane (Bologna, 1582). In: BAROCCHI, P. Trattati d'arte del Cinquento fra Manierismo e Controriforma, II. Bari, 1961.

STOICHITA, V. I. Visionary Experience in the Golden Age of Spanish Art. London: Reaktion Books, 1995.

THOM, R. Local et global dans l'oeuvre d'art. Le débat, 24, 1983, p. 73-89.

TORE, G. M. L'énonciation comme concept clé des sciences du langage: peut-on la definir? In: COLAS-BLAISE, M.; PERRIN, L.; TORE, G. M. (dir.). L'énonciation aujourd'hui: un concept clé des sciences du langage. Limoges: Lambert-Lucas, 2016, Post-scriptum.

Submetido em: 10-8-2021

Aceito em: 11-10-21 